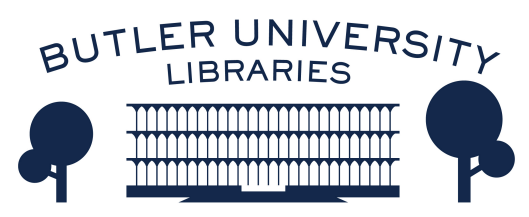

Journal of Hindu-Christian Studies

Volume 20

Article 12

January 2007

\title{
Integral "Samnyasa"? Adi Shankaracharya and Liberation Hermeneutics
}

Reid B. Locklin

Follow this and additional works at: https://digitalcommons.butler.edu/jhcs

Part of the Religion Commons

\section{Recommended Citation}

Locklin, Reid B. (2007) "Integral "Samnyasa"? Adi Shankaracharya and Liberation Hermeneutics," Journal of Hindu-Christian Studies: Vol. 20, Article 12.

Available at: https://doi.org/10.7825/2164-6279.1387

The Journal of Hindu-Christian Studies is a publication of the Society for Hindu-Christian Studies. The digital version is made available by Digital Commons @ Butler University. For questions about the Journal or the Society, please contact cbauman@butler.edu. For more information about Digital Commons @ Butler University, please contact digitalscholarship@butler.edu. 


\title{
Integral Samnyasa? Adi Shankaracharya and Liberation Hermeneutics
}

\author{
Reid B. Locklin \\ University of Toronto
}

\begin{abstract}
As many of you as were baptized into Christ have clothed yourselves with Christ. There is no longer Jew or Greek, there is no longer slave or free, there is no longer male and female (Galatians 3:27-28).
\end{abstract}

WRITING in the Women's Bible Commentary, Carolyn Osiek offers five conflicting interpretations of this controversial passage and its significance for women's liberation. At one end of the spectrum stand those who insist that the text "endorses an end to sexism of every kind," a difficult view to square with other statements of the apostle Paul. At another extreme stand those who ascribe it exclusively to a future transformation at the end of time, with no contemporary relevance. ${ }^{1}$ Other views lie somewhere between these extremes, including a suggestion that

. . . in God's future the tension between human opposites-Jew and Gentile, slave and free, male and female-will disappear. Because life in the grace of Christ anticipates in part what the future can be like, it is possible to live without these unhealthy tensions even now. ${ }^{2}$

Though this is not the only alternative offered by Osiek, it reveals a hermeneutical strategy employed by a number of Christian liberationists. In $A$ Theology of Liberation, for example, Gustavo Gutiérrez similarly argues that scriptural texts such as the Exodus narrative or Romans 8 emerge in a new light when one "sees in the world beyond not the 'true life,' but rather the transformation and fulfillment of the present life." ${ }^{3}$ Borrowing language from Rita Sherma, we might say that such liberationist interpretations hinge upon establishing a strong connection between a theological vision of the "ultimate goal" of human life and a social vision of "penultimate" ethical values in the here and now. ${ }^{4}$

In this essay, I would like to suggest that a comparable hermeneutical strategy can be discerned in selected arguments of the Hindu teacher Adi Shankaracharya. At first glanceeven a sustained first glance-the non-dualist theology of Shankara and his followers would seem an unlikely source for a world-affirming view of human life and political transformation. Sherma herself suggests that Shankara represents a particularly striking example of the general Hindu trend to neglect "the relevance of moksa to dharma," and S.L. Malhotra has noted the tendency among some modern Advaitins to reject Shankara or radically to reinterpret his teaching in the interests of social activism. ${ }^{5}$ One influential such re-interpretation is the so-called "Tat-Tvam-Asi Ethic" developed by Paul Deussen and adopted by Vivekananda and other neo-Vedantins: that is, the idea that recognition of the same self in all beings can directly motivate egalitarian concern. This interpretative strategy has, however, been roundly criticized

Reid B. Locklin holds an assistant professorship in Christianity and the Intellectual Tradition at the University of Toronto (Saint Michael's College). He has published articles and book chapters in the areas of Christian ecclesiology and Hindu-Christian comparative theology, as well as a slim volume in spirituality entitled Spiritual but Not Religious? An Oar Stroke Closer to the Farther Shore (Liturgical Press, 2005). He is in the process of completing a Christian theological commentary on Shankara's Upadesasahasri, to be published by Peeters Press. 
by Paul Hacker and Karl Potter on exegetical and philosophical grounds. ${ }^{6}$ Whether or not one accepts this critique, it does suggest that arguing for the social relevance of Advaita teaching remains an important, ongoing and unfinished task in the tradition.

Taking up this challenge, Anantanand Rambachan has recently modeled a "top down" approach, questioning traditional Advaita distinctions between "qualified" and "unqualified" Brahman. By setting these two characterizations of Brahman in a paradoxical mutual relation rather than in hierarchical order, he suggests, the Advaitin interpreter can recover a positive sense of divine creatorship and worldaffirming social action. ${ }^{7}$ I propose a different tack in this essay, building "from the bottom up" by identifying just one point on which Shankara himself consistently drew definite social consequences from his teaching on final liberation: the highly disputed issue of worldrenunciation (samnyasa). In his avid defence of samnyasa, I argue, Shankara implicitly problematizes his own social conservatism, thereby opening a door to a broader HinduChristian conversation about liberation hermeneutics and social reform.

\section{Shankara's Teaching on Samnyasa: Sine Qua Non or Non-Exclusive Norm?}

There is a voluminous body of scholarship on Shankara, of course, much of it dealing with his teaching on samnyasa. One fairly recent contribution is Roger Marcaurelle's Freedom through Inner Renunciation. ${ }^{8}$ In this exhaustive study, Marcaurelle makes a case-against the weight of prior interpretation, traditional and modern-that Shankara did not view the breaking of the sacred thread, abandonment of ritual and adoption of renunciant life as a "sine qua non" for liberation. It is "direct Selfknowledge" and the accompanying interior "renunciation of doership" (kartrtva-samnyasa) that stand at the centre of Shankara's vision, making liberation accessible to anyone, regardless of caste, gender or state of life. ${ }^{9}$ Entrance into the fourth stage of life through physical renunciation (karma-samnyasa) represents one particularly helpful means, albeit one restricted by Shankara to members of the
Brahmin caste, for supporting the pursuit of direct Self-knowledge. "It is clear," Marcaurelle claims, "that for the seeker-after-liberation the value of physical renunciation lies in allowing full-time dedication to the most direct means of Self-knowledge, and not in being the only way of living capable of bringing about that knowledge."10

Marcaurelle's account is attractive, not least because it attempts to free the Advaita tradition from monastic elitism. ${ }^{11}$ Yet Marcaurelle's interpretation is weakened, in my judgement, by the very narrow scope of his enquiry. He asks, "according to Shankara, is physical renunciation a necessary indirect means .for liberation?"12 The answer to this question may well be negative. But our perspective might nevertheless be enriched by approaching the same data with a broader, less reductive question in mind. Specifically, we can gain a broader view on Shankara's teaching if we ask how and why he upholds karma-samnyasa as a central, governing norm for liberating Self-knowledgewhether absolutely necessary, or not.

That Shankara gives this samnyasa some normative significance emerges clearly from two texts Maurcarelle finds most difficult to harness to his thesis: Brahma-Sutra-Bhasya 3.4.20 and the independent treatise Upadesasahasri. ${ }^{13}$ In the most relevant adhikarana of the BrahmaSutra-Bhasya, Shankara vigorously defends the legitimacy of samnyasa as the state of life proper to those who remain "steadfast in Brahman" (Brahma-samstha), on the evidence of Chandogya Upanishad 2.23.1 and the Jabala Upanishad, against Purva-Mimamsa objections." "The term "steadfastness in Brahman," he writes, "implies a consummation in Brahman, a total absorption in Brahman, which is the same as absence of any other preoccupation except that. And that is not possible for people in the other three stages," due to their preoccupation with ritual obligations and other duties. ${ }^{15}$ The special status of samnyasa is underscored in the Upadesasahasri, especially its first prose chapter, where the ideal student of Advaita is explicitly described as a Brahmin renunciant of the paramahamsa order. ${ }^{16}$ Elsewhere, Shankara will take such affirmations one step further, associating the discipline of knowledge so closely with 
paramahamsa ascetics as, by all appearances, to restrict liberation to these persons alone. ${ }^{17}$

Marcaurelle readily allows Shankara's very strong emphases upon Brahmin caste and physical renunciation, as well as their close mutual connection, but he grants such emphases merely concessive force:

Although Sankara understood his teaching to be accessible to all castes, for sociohistorical and/or strategic reasons, in practice, he may have taught mainly to Brahmins, who were probably the most qualified to understand the subtle argumentation of his revival . . . Additionally, Sankara's specific mention of physical renunciation as a requirement for the discipline of knowledge in the [Upadesasahasri] may have been a way to emphasize that, because physical renunciation allows full-time dedication to enquiry into the nature of Brahman-Atman, it is most supportive of Self-knowledge and therefore preferable for those who are qualified for it. ${ }^{18}$

According to Marcaurelle, then, Shankara presumes samnyasa as a norm for purely pragmatic or contextual reasons, arising from his social and historical location.

No doubt this captures part of the reality. Most modern scholars would be surprised if Shankara's teachings were not highly influenced by the context(s) in which he formulated them. A more intriguing possibility arises, however, by taking the great teacher at face value. Shankara's teaching represents one moment of interpretation in the ongoing "theological construction" of samnyasa in relation to the other asramas, so ably documented by Patrick Olivelle in a major study. ${ }^{19}$ As one of many such interpreters, Shankara articulates his views in self-conscious dialogue and argument with alternate views. And, while certainly distinguishing different valences of samnyasa as both state of mind and state of life, he nevertheless holds these various meanings in a close, creative and deliberate relation that resists being so easily relativized by appeal to social context.
A good point of entry for exploring this essential relation is a 1982 essay by Karl Potter, who contends that, for Shankara, "true samnyasa is the same thing as liberation." 20 Potter's argument proceeds from the nature of Selfknowledge itself. If, as Shankara repeatedly asserts, there is a basic contradiction between any sense of personal agency and true knowledge devoid of such agency, then there is also a basic contradiction between a life dominated by worldly activity (pravrtti) and its opposite, a life of inactivity or withdrawal (nivrtti). From this observation, supported by Shankara's discussions of "true mendicancy" in the Chandogya-Upanishad-Bhasya 2.23.1 and Brhadaranyaka-Upanishad-Bhasya 3.5.1, Potter rejects samnyasa as a step toward liberation. Genuine samnyasa represents, instead, liberation's natural and inevitable consequence-a social expression, we might say, of the Self-knower's non-dual awareness, which no longer differentiates castes or stages of life nor desires to benefit by performing any action. ${ }^{21}$ From this point of view, samnyasa is not really an asrama at all; it is better characterised as ati-asrama, a profound transcendence of ignorance, duality and all those states and duties premised upon them. ${ }^{22}$

Potter's insight here is of central importance, but he also overstates his case. In point of fact, Shankara does place great value on samnyasa, even prior to Self-knowledge. Interestingly, he typically constructs this argument in a kind of reverse order, reasoning analogically from the renunciant life of the liberated Self-knower to renunciation as a means of liberation. His introduction to the AitareyaUpanishad-Bhasya is a good case in point. In this extended debate, after first defending the renunciation that follows naturally (arthaprapta) from Self-knowledge, Shankara draws a further conclusion:

Even for the one who is devoid of enlightenment, but is desirous of liberation, the life of a wandering mendicant is [also] enjoined. The teaching such as, 'Knowing this, he becomes self-controlled and calm' [Brhadaranyaka-Upanishad 4.4.23] bears testimony to it. The disciplines such as mental tranquility and self-restraint, which 
are the means for the perception of the Self, have no significance as far as the other stages of life are concerned. ${ }^{23}$

Marcaurelle observes a similar strategy in Shankara's comment on BrhadaranyakaUpanishad 4.4.22 and 3.5.1, where it is the renunciation of the ancient sages that sets the standard for contemporary seekers. "Paradoxically," Marcaurelle writes, "those who physically renounced only after enlightenment serve as model and inspiration for taking recourse to physical renunciation before enlightenment." 24 Shankara adduces both scriptural warrants and practical arguments to defend samnyasa for seekers as well as Selfknowers, but his basic conviction arises from the nature of liberation itself, which entirely sublates the distinctions of ordinary life. If such liberating Self-knowledge naturally conduces to renunciant life, it seems reasonable that renunciant life would also conduce to the acquisition of such knowledge. They represent flip sides of the same coin.

But, to press the question, does this mean that renunciation represents the only kind of life that can lead to liberation? It seems not, at least not without exception. Marcaurelle, as we have seen, argues for the universality of Shankara's essential vision, based primarily upon the several Upanishadic examples of Selfknowledge arising in women, members of lower castes, and others ineligible for samnyasa. Above all, this includes the BrhadaranyakaUpanishad's great king Janaka, who persists in worldly life even after achieving Selfknowledge. Other interpreters may demur. Lance Nelson, for example, suggests that, although Shankara does allow for exceptions to the narrow restriction of liberation to Brahmin renunicants, these "appear to be only such as were necessitated by scriptural passages suggestive of the more liberal attitude of an earlier age, and which therefore called the later restrictions into question." 25 Either way, I think a case could be made that Shankara explains whatever variations he $i$ s willing to admit by reasoning analogically from the more fundamental and normative state of samnyasa. Whether because of his Ksatriya caste or his kingly duties, Janaka cannot take up renunciant life. But Shankara describes the life he does lead as "samnyasa-like," consisting of motiveless action for the good of the world. ${ }^{26}$ Renunciation may not be a "sine qua non" for liberation; it functions, instead, as a powerful norm that frames Shankara's approach even to those cases that deviate significantly from this same norm. ${ }^{27}$

And why would samnyasa, even karmasamnyasa, possess such normative status for seeker-after-liberation and Self-knower alike? Precisely because the moksa of the liberated sage has a natural and spontaneous correlate in the particular social conditions of renunciant life. Stated another way: for Shankara, at least one kind of penultimate social reality can and should be re-shaped in light of theological convictions about final release. Moksa, in this case, has definite consequences in the realm of dharma . . . which brings us squarely back to liberation hermeneutics.

\section{Marks and Means of Liberation: Broadening Our View}

To explore the liberative potential of this otherwise highly conservative argument about samnyasa, we can turn to the work from which Marcaurelle draws his strongest support: Shankara's commentary on the BhagavadGita. $^{28}$ Now, among the writings that merited a full bhasya by the great teacher, the Gita is probably the least amenable to a consistent Advaitin reading. ${ }^{29}$ This makes the GitaBhasya, perhaps, a less than ideal source for discerning Shankara's fundamental convictions on any issue, constrained as he is by the text upon which he comments. But for our purposes-and possibly for the interpretation of Shankara generally-fundamental "positions," as such, may be less illuminating than the hermeneutical and pedagogical methods from which they arise. ${ }^{30}$ Precisely because the Gita presents difficulties, the Gita-Bhasya emerges as a rich demonstration of Shankara's theological creativity. It thus becomes a rich source for discerning principles of creative re-interpretation in the present.

Shankara does not disappoint on this score. To introduce Krishna's extended description of the "person of steady wisdom" at the end of 
chapter 2, for example, he introduces an intriguingly novel interpretative rule:

In the verses from 2.55 to the end of the chapter are taught the characteristics of, and the means employed by, the sage of stable wisdom who concerns himself with the discipline of knowledge. He does so either after renouncing actions right from the beginning, or he may have become a sage practicing karma yoga. For, in all texts on the science of the Self, the very characteristics of the perfected sage have been set forth as means to be cultivated [by the aspirant] ... The blessed Lord recounted these [characteristics] that are at once the means, demanding effort, and also the marks. $^{31}$

Marcaurelle cites this text to substantiate Shankara's "polysemic" and ambiguous terminology of samnyasa. ${ }^{32}$ To my mind, however, it also reads as a creative extension and generalization of the hermeneutical moves we already saw at work in the AitareyaUpanishad-Bhasya.

There, Shankara first argued that true samnyasa proceeds naturally (artha-prapta) from liberating 'Self-knowledge; from this primary argument, it followed that renunciant life could be legitimated as the ordinary means to pursue such knowledge. Here, on the other hand, Shankara concedes that persons do in concrete fact come to knowledge either by taking up renunciant life "right from the beginning" (aditah) or by living first as a householder. Along the way, however, he also makes a strong claim about the close relation of marks (laksana) and means (sadhana) in this process.

In the Advaita context, of course, speaking of something as a "means" (sadhana) of liberation cannot imply that liberation, as such, becomes something that is produced through effort. Instead, Shankara seems to be speaking in terms of coherence and suitability, as we have already seen with reference to renunciant life. If samnyasa is a spontaneous, defining mark or characteristic (laksana) of the liberated sage, then it also becomes-ipso facto-something to be cultivated by the seeker after liberation. It can thus be called, analogically, a sadhana of liberation. The seeker is evidently enjoined to assume those distinctive patterns of life and thought appropriate to a liberated person as part of a process of habituation and assimilation, closely coordinated with the acquisition of knowledge itself. When these habits have become second nature, arising naturally from one's fundamental disposition, then seekers themselves become ever more transparent to the liberating reality they so assiduously pursue. ${ }^{33}$

All of this coheres well with what we have seen thus far. The difference is that, in the GitaBhasya, the rule is extended in principle to any defining mark of liberation, not merely to renunciant life narrowly defined. Such an extension may initially seem quite undramatic, even uninteresting. In Gita 2.55-72, for example, the further characteristics offered as both marks and means of liberation consist of precisely those dispositions and disciplines we might expect: mental restraint, detachment and personal equanimity.

If we turn to a different text, however, a creative extension of this same principle might yield more startling results. Consider these verses, from the Gita's fifth chapter:

[These] wise ones see the self same thing in a Brahmin wise and courteous as in a cow or an elephant, nay, as in a dog or outcaste. While yet in this world they have overcome [the process of] emanation [and decay], for their minds are stilled in thatwhich-is-ever-the-same: for devoid of imperfection and ever-the-same is Brahman: therefore in Brahman.[stilled] they stand (Gita 5.18-19). ${ }^{34}$

Now, just as the Galatians passage with which we started this essay does not selfevidently preclude sexism, so also this passage does not self-evidently preclude class division or animal exploitation. Given some of Krishna's other teaching in the Gita, it is difficult to imagine a radically egalitarian intention behind the text.

Notwithstanding such reservations, Gita 5.18-19 does speak of a transformation of consciousness with potentially profound social implications, of a wise person who sees the same 
undefiled Brahman in an upper class Brahmin, socially inferior outcaste, cow, elephant and dog. Shankara's comment on the verses, moreover, reveals two quite different-and mutually conflicting-trajectories. On the one hand, he reaffirms and even reifies the implied social hierarchy by emphasizing the metaphysical goodness (sattva) of the Brahmin, passion (rajas) of the cow, and darkness (tamas) of elephant, dog and outcaste, as well as the inherent merit and demerit that constitutes each class. At the same time, when confronted with a prohibition against "treating unequals as equals" from the Dharma-sastra literature, Shankara insists that those who abide in Brahman transcend merit and demerit ... including the specific demerit of transgressing the boundaries of class: "The aphorism [from the Dharmasastra] refers to works. On the other hand, the matter under consideration from 5.13 to the end of the chapter refers to the renunciation of works [sarva-karma-samnyasa]." 35 Having identified completely with the Self free from defilement, we might say, the liberated sage becomes free to relate to all persons and all creatures with an eye to their ultimate equality. Not everyone shares the same rights and privileges in society, to be sure, but the wise person can see them as equal and may even be interpreted to be empowered to act accordingly, regardless of the restrictions placed by sastra.

Shankara himself balances both sides of this equation with great delicacy, juxtaposing fundamental convictions about equality and inequality without advocating social revolution. A. more radical reading might press the question by importing Shankara's own principle of marks and means, asking whether and to what degree a theological vision of the liberated state might have social consequences. If an attitude of profound equality is a distinguishing characteristic (laksana) of the liberated sage, can it also be considered a privileged means (sadhana) of liberation? More specifically, what are the social conditions that proceed naturally and spontaneously (artha-prapta) from such a vision, and how might these social realities also become the objects of assiduous striving on the part of those seeking final release? Might not the seeker after liberation, like the Christian disciple who is striving to live "in Christ," be empowered by the radical, non-dual teaching of Advaita to anticipate final liberation through actions that bring that ultimate vision to bear on present social realities and institutions? ${ }^{36}$

Answers to such questions cannot be determined in advance, and one might expect diverse, even controversial positions to arise in addressing them. Indeed, a sympathetic Advaitin interpreter would presumably require much more than this single principle of interpretation: further scriptural warrants and pragmatic arguments would need to be adduced as supports for such a liberative extension of the text, as we also witness in Shankara's defence of samnyasa. ${ }^{37}$ Yet the central insight, here as there, would have to follow from the nature of Self-knowledge itself. Shankara does not decide the case for us. He does, however, open a hermeneutical door for others-Hindu and Christian alike - to enter.

\section{From Inner Renunciation to Integral Renunciation: A Hermeneutical Conversation}

Some Christians have begun speaking in terms of "integral salvation" to make clear that the transformation of this-worldly political and social realities lies squarely within the purview of Christian soteriology. Such language has even made it into official documents of the Catholic Church. In 1974, for example, participants in the Church's Fourth Synod of Bishops offered the following reflection:

Among the many matters treated at the Synod we paid particular attention to the problem of the inter-relation between evangelization and integral salvation, or the full liberation of man [sic] and peoples.... For every man and for the whole of society the gospel is the good news of a salvation which must commence and be manifested on earth, for all that its full achievement must await the after-life. ${ }^{38}$

The expressions "integral salvation" and "integral liberation" were subsequently incorporated into future synod declarations and papal statements, as well as the 1986 
"Instruction on Christian Freedom and Liberation" by the Vatican Congregation for the Doctrine of the Faith. ${ }^{39}$

In light of this important Christian development, as well as the preceding analysis, I suggest that we might also begin to imagine something like "integral samnyasa" as a latent principle of Shankara's teaching. If, as Potter suggests, "true samnyasa is the same thing as liberation," then integral samnyasa would comprehend the sum-total of social conditions that might proceed spontaneously from, and therefore also lead naturally to, liberating Selfknowledge. ${ }^{40}$ This could include, in addition to withdrawing from worldly desire and a striving after the fruits of action, also transforming those unjust conditions that do not naturally cohere with the non-dual vision of the liberated sage. Thus, from a liberative reading of Gita 5.18-19, one might discern a new basis for a distinctively Advaitin critique of class inequity or destructively anthropocentric social policy. Such a critique would, no doubt, exist in tension with some explicit statements of Krishna in the Gita and especially of Shankara himself. But it could, nevertheless, claim consistency with the great Advaitin teacher's basic hermeneutical principles.

If this proposal has any merit, then it seems to me that it significantly alters the way we

\footnotetext{
Notes

Carolyn Osiek, "Galatians," in Women's Bible Commentary, ed. Carol A. Newsom and Sharon H. Ringe, rev. ed. (Louisville: Westminster Knox Press, 1998), p. 425.

${ }^{2}$ Ibid.

3 Gustavo Gutiérrez, A Theology of Liberation: History, Politics, and Salvation, rev. ed., trans. Sister Caridad Inda and John Eagleson (New York: Orbis Books, 1988), p. 85.

${ }^{4}$ Rita Sherma, "Eros, Ethics, and Enlightenment: Toward a Reconstructive Approach to Ultimate and Penultimate Goals in Hindu Theology," Infinity Foundation, http:/Wwin.infunity foundation,com/mandala/s es she rm eros.htm, accessed 17 February 2006.

${ }^{5}$ See Ibid. and S.L. Malhotra, Social and Political Orientations of Neo-Vedantism: Study of the Social Philosophy of Vivekananda, Aurobindo, Bipin Chandra Pal, Tagore, Gandhi, Vinoba, and Radhakrishnan (New Delhi: S. Chand and Company,
}

evaluate Shankara and his contemporary relevance. Perhaps most importantly, such a notion of integral samnyasa could counter a trend, evident in the work of Marcaurelle and others, to identify the universalist potential of Advaita teaching too quickly and completely with its perceived focus upon interiority. ${ }^{41}$ As I have tried to argue here, a quite different approach would give greater credence to Shankara's highly realistic insistence upon the close correspondence between liberating knowledge and very particular conditions of social life, at least in some contexts. ${ }^{42}$ Therein lies the seed of a different kind of universalism-a universalism that, as the Christian liberationist Gutiérrez observed a number of years ago, reaches not only to all persons but also to whole persons, including the political and economic structures in which they concretely exist. ${ }^{43}$

Was Shankara a liberationist interpreter? Almost certainly not: But his teaching may nonetheless make a helpful contribution to ongoing Hindu-Christian conversations, not only about ultimate goals or penultimate ethical values in and of themselves, but also about how we reason theologically to connect one to the other. $^{44}$

1970), 6, 31-33. The task of motivating the fundamental teachings of Advaita for social justice and political transformation has been a central concern for many neo-Vedantin apologists. See Wilhelm Halbfass, India and Europe: An Essay in Understanding (Albany: State University of New York Press, 1988), esp. pp. 23.8-42.

6 See Paul Hacker, "Schopenhauer and Hindu Ethics," in Philology and Confrontation: Paul Hacker on Traditional and Modern Vedanta, ed. Wilhelm Halbfass (Albany: State University of New York Press, 1995), pp. 273-318, and Karl H. Potter, "Introduction to the Philosophy of Advaita Vedanta," in Encyclopedia of Indian Philosophies: Advaita Vedanta up to Samkara and His Pupils (Princeton: Princeton University Press, 1981), pp. 36-38, as well as Andrew O. Fort, "Jivanmukti and Social Service in Advaita and Neo-Vedanta," in Beyond Orientalism: The Work of Wilhelm Halbfass and its Impact on Indian and Cross-Cultural Studies, ed. Eli Franco and Karin Preisendanz, Poznan Studies in the Philosophy of the Sciences and the Humanities 59 
50 Reid B. Locklin

(Amsterdam and Atlanta: Rodopi, 1997), pp. 489504.

Anant Rambachan, "Hierarchies in the Nature of God?" Hindu-Christian Studies Bulletin 14 (2001): pp. 13-18, and Anantanand Rambachan, The Advaita Worldview: God, World, Humanity (Albany: State University of New York Press, 2006), esp. pp. 67-97.

8 Roger Marcaurelle, Freedom through Inner Renunciation: Sankara's Philosophy in a New Light (Albany: State University of New York Press, 2000).

${ }^{9}$ See ibid., esp. pp. 15-20, 29-40.

${ }^{10}$ Ibid., p. 210.

${ }^{11}$ On this point, see especially Jeffrey D. Long's review in The Journal of Religion 81 (2001): pp. 15859.

${ }^{12}$ Marcaurelle, Freedom, p. 29 (emphasis added).

${ }^{13}$ See ibid., pp. 32-40 and 139-42.

14 Brahma-Sutra-Bhasya 3.4.18-20, in Swami Gambhirananda, trans., Brahma-Sutra-Bhasya of Sri Sankaracarya (Calcutta: Advaita Ashrama, 1993), 770-78. Cf. Francis X. Clooney, S.J., Theology after Vedanta: An Experiment in Comparative Theology (Albany: State University of New York Press, 1993), pp. 141-49, and Patrick Olivelle, The Asrama System: The History and Hermeneutics of a Religious Institution (New York and Oxford: Oxford University Press, 1993), pp. 226, 239-42.

${ }^{15}$ Brahma-Sutra-Bhasya 3.4.20, in ibid., p. 776.

${ }^{16}$ See Upadesasahasri, Prose Portion 1.2. Sanskrit text and English translation in Swami Jagadananda, trans., A Thousand Teachings, in Two Parts-Prose and Poetry, of Sri Sankaracharya, (Madras: Sri Ramakrishna Math, [1941]), p. 2.

${ }^{17}$ E.g. Bhagavad-Gita-Bhasya 3.3. Sanskrit text and English translation in A.G. Krishna Warrier, trans., Srimad Bhagavad Gita Bhasya of Sri Samkaracarya (Madras: Sri Ramakrishna Math, 1983), pp. 101-103. See also Lance Nelson, "Theism for the Masses, Non-Dualism for the Monastic Elite: A Fresh Look at Samkara's Trans-Theistic Spirituality," in The Struggle over the Past: Fundamentalism in the Modern World (Lanham: University Press of America, 1993), esp. pp. 72-74.

${ }^{18}$ Marcaurelle, Freedom, p. 39.

${ }^{19}$ See Olivelle, The Asrama System, pp. 24-27 and passim.

${ }^{20}$ Karl H. Potter, "Samkaracarya: The Myth and the Man," Journal of the American Academy of Religion Thematic Studies 48.3-4 (1982): p. 120.

${ }^{21}$ Ibid., pp. 115-18.

${ }^{22}$ See Olivelle, The Asrama System, pp. 224-26, and Marcaurelle, Freedom, pp. 131-42.

${ }_{23}$ Aitareya-Upanisad-Bhasya introduction. Sankrit text and English translation in V. Panoli, trans., Upanishads in Sankara's Own Words, vol. 2, rev. ed.
(Calicut: Mathubhumi Printing and Publishing Company, 1996), pp. 448-49. I have modified the English translation.

${ }^{24}$ Marcaurelle, Freedom, p. 147.

${ }^{25}$ Nelson, "Theism for the Masses," p. 74n43.

${ }^{26}$ See, e.g., Shankara's comment on Bhagavad-Gita 3.19-22 and 4.19-20, in Krishna Warrier, pp. 116-17, 154-56. Cf. Marcaurelle, Freedom, pp. 74-130 and Kapil N. Tiwari, Dimensions of Renunciation in Advaita Vedanta (Delhi: Motilal Banarsidass, 1977), esp. pp. 115-20. The other great paradigm of the "activist" (pravrtta) Self-knower is, of course, Lord Krishna. For creative developments of this theme, see Lance E. Nelson, "Living Liberation in Sankara and Classical Advaita: Sharing the Waiting of God," in Living Liberation in Hindu Thought, ed. Andrew O. Fort and Patricia Y. Mumme (Albany: State University of New York Press, 1996), pp. 17-62, and Jacqueline Gaynor Suthren Hirst, The Teacher and the Avatara: Mediators of Realisation in Samkara's Advaitin Theology (Ph.D. Dissertation, University of Cambridge, 1983).

${ }^{27}$ Marcaurelle objects briefly but strenuously to the notion that Janaka constitutes a rare "exception" to the general rule that seekers are obligated take up samnyasa in the pursuit of self-knowledge (Freedom, pp. 46-47). In my judgement, shifting the language from "rule and exception" to "norm and variations" nicely addresses Marcaurelle's main concerns while also preserving the centrality of samnyasa in Shankara's thought.

${ }^{28}$ See especially Marcaurelle, Freedom, pp. 55-81, as well as Roger Marcaurelle, "The Basic Types of Renunciation in Hinduism: with Special Reference to Sankara's Gita-Bhasya," in Hermeneutical Paths to the Sacred Worlds of India: Essays in Honour of Robert W. Stevenson, ed. Katherine K. Young (Atlanta: Scholars Press, 1994), pp. 104-22, and Roger Marcaurelle, "Sankara's Hermeneutics of Renunciation in the Gita," in New Essays in the Bhagavadgita: Philosophical, Methodological, and Cultural Approaches, ed. Arvind Sharma (New Delhi: Books and Books, 1987), pp. 98-126.

${ }_{29}$ See, e.g., the discussion in R.C. Zaehner, trans., The Bhagavad-Gita, with a Commentary Based on the Original Sources (London, Oxford and New York: Oxford University Press, 1969), esp. pp. 7-9.

30 See especially J.G. Suthren Hirst, Samkara's Advaita Vedanta: A Way of Teaching (London and New York: RoutledgeCurzon, 2005), pp. 69-88.

${ }^{31}$ Gita-Bhasya 2.55.0, in Warrier, p. 76 (modified).

${ }^{32}$ Marcaurelle, Freedom, pp. 12, 148.

${ }^{33}$ Cf. Clooney, Theology after Vedanta, pp. 141-49; Rambachan, Advaita Worldview, pp. 19-21.

${ }^{34}$ In Zaehner, p. 63 (modified). 
${ }^{35}$ Gita-Bhasya 5.18-19, in Warrier, pp. 201-204.

${ }^{36}$ On this point, see Rambachan, Advaita Worldview, p. 28: "Criticism of caste inequality, as far as the knowledge of brahman is concerned, can also find justification in the Advaita teaching about the identity and sameness of the self in all beings. It remains a matter of concern that the greatest historical exponent of this teaching remained untroubled by social inequality, a contradiction that is still not uncommon." Cf. Tiwari's conclusion in Dimensions of Renunciation, p. 142: "Renunciation consists essentially in transforming the nature of man [sic] and the universe - a transformation whose accomplishment consists in manifesting or letting the true nature of them to emerge to the surface."

37 Arvind Sharma offers a helpful cluster of such additional supports in "Sankara"s Life and Works as a Source for a. Hermeneutics of Human Rights," in New Perspectives on Advaita Vedanta: Essays in Commemoration of Professor Richard DeSmet, S.J., ed. Bradley. J. Malkovsky, Numen Book Series 85 (Leiden: Brill, 2000), pp. 109-21.

${ }^{38}$ Quoted in Francis A. Sullivan, S.J., The Church We Believe In (New York/Mahwah: Paulist Press, 1988), p. 141.

${ }^{3939}$ See ibid., pp. 132-51.

40 This proposal dovetails in some ways with Marcaurelle's intriguing treatment of adhikara as "having to do with" rather than "qualification" or "requirement for" Self-knowledge, precisely because it is ascribed to Self-knowers and seekers alike. See Freedom, pp. 41-44:

${ }^{41}$ See especially Thomas Forsthoefel, "The Sage of Pure Experience: The Appeal of Ramana Maharsi in the West," Hindu-Christian Studies Bulletin 14 (2001): pp. 31-36, as well as his Knowing Beyond Knowledge: Epistemologies of Religious Experience in Classical and Modern Advaita, Ashgate World Philosophies (Hants and Burlington: Ashgate Publishing, 2002).

${ }^{42}$ For realist approaches to Shankara's thought, see Hirst, Samkara's Advaita Vedanta, pp. 94-115; Malhotra, Social and Political Orientations, esp. pp. 31-50; Rambachan, Advaita Worldview, esp. pp. 6781; and Francis X. Clooney, S.J., "Samkara's Theological Realism: the Meaning and Usefulness of Gods (devata) in the Uttara Mimamsa Sutra Bhasya," in Malkovsky, New Perspectives, pp. 30-50. Bradley Malkovsky also offers a helpful survey of illusionist and realist strands of Advaita interpretation in his article "The Personhood of Samkara's Para Brahman," The Journal of Religion 7.7 (1997): pp. 541-62.

${ }^{43}$ Gutiérrez, pp. 83-86.
$4^{4}$ ' I am very grateful to Jennifer Harris, Hugh Nicholson, Michael Stoeber, three anonymous reviewers, and Bradley Malkovsky for their helpful comments and suggestions on various stages of this essay. 